DOI: 10.24234/wisdom.v14i1.327

Natalia KUTUZA,

Inna KRAVETS

\title{
LINGUOPHILOSOPHICAL ASPECT OF COMMUNICATIVE INFLUENCE: THEORETICAL BASIS
}

\begin{abstract}
The article deals with the phenomenon of communicative influence in linguistics and philosophy. The subject of the study was the theoretical basis of communicative influence. The purpose of this article is to consider communicative influence in linguophilosophical aspect. A number of research methods have been used to achieve this goal: descriptive; specifics; method of analysis and synthesis; modeling method; induction method.

It is found that philosophers have focused their attention on the "magic" of the word when studying influence; close connection of spirit, soul with language, psychophysiological phenomena; inaccuracies and variability of interpretation of reality; language as activity, motives for action. In the linguistic aspect, in the light of new and emerging disciplines, attention is focused on the variability, imagery, associative potential of lexemes and linguistic complexes, which is a suggestogenic potential, which is analyzed at all linguistic levels. Emphasized that the language in general is suggestive phenomenon. The authors propose to consider the impact actualizers (suggestems/suggestogens) according to the degree of suggestiveness manifestation, where implementation at two language levels is weak actualization, at three - moderate, more than three - strong.
\end{abstract}

Keywords: communicative influence, linguistics, language, degree of intensity, suggestion, philosophy.

Introduction

Communicative influence is an interdisciplinary subject for the study of the natural, social and human sciences, each of which analyses a separate component of this multicomponent, complex phenomenon. The integration of the philosophical, medical, psychological, pedagogical and other fields of knowledge makes it possible to make a stereometric approach to the study of influence and its maximum ecological application in the modern communicative space, which emphasizes the relevance of the proposed article.

The purpose of the article is to consider communicative influence in the linguistic and philosophical aspect. The purpose is to solve the following tasks: to find out the philosophical and linguistic nature of influence; outline the influential potential of language; to identify the main factors that formed the basis of the linguistic teaching of communicative influence.

The philosophical aspects of influence and suggestion as a variety of it were touched upon 
by scientists $H$. Weihinger, L. Wittgenstein, $H$. G. Gadamer, M. Heidegger, G. A. Goncharov, E. Husserl, A. Korzhibsky, I. Y. Cherepanova and many other researchers, since "The comprehension of the essence of man, his consciousness, soul, sense of existence occurred in accordance with the problems of the influence of language" (Cherepanova, 2001, p. 26). Scientists in the process of thinking about language, its influence on the spiritual world of man, his views and actions, etc. focused their attention on such issues as the "magic" of the word (R. Barthes, M. Heidegger, J. Lacan, P. Florensky); close connection of spirit, soul with psychophysiological phenomena, with language (M. Heidegger, G. A. Goncharov, V. Humboldt, R. Y. Kies, O. O. Potebnya) and the influence of language on the world perception of man (V. Humboldt, L. Weisgerber, E. Sapir, B. Worf); the inaccuracy and variability of the interpretation of reality (F. Bacon, M. Heidegger, A. Korzhibski, J. Locke); language as activity, motives for action (H. Weihinger, L. Wittgenstein) and others.

Linguistic aspects of influence were also interested in Ancient Greece and Rome, where "the Sophists proposed the practice of influencing the art of conducting ethical debates, as well as the principle of lobbying, that is, the desire to persuade legislators the ability to persuade" (Manakin, 2011, p. 197). Scientific systematic study of influence as a constant of communication falls in the 40-60's in the West, in the 6080 's of the twentieth century. in the Soviet Union and is carried out mainly within the limits of psycholinguistics in the works of such famous scientists as R. Blakar, T. M. Dridze, P. Lazarfeld, G. Lasswell, O. O. Leontiev, O. I. Negnevitskaya, M. Rubakin, L. V. Sakharnyi, Y. O. Sorokin, E. F. Tarasov, L. Howland, and others.

The current state of study of communicative influence is noted by the increased attention of both Ukrainian and foreign scientists (D. Aaker, I. M Dzialoshynsky, V. G. Zazykin, A. P. Zagnitko, S. G. Kara-Murza, T. Y. Kovalevska, G. A. Kopnina, O. O. Selivanova, N. V. Chumicheva, etc.), which rely not only on classical linguistic directions (rhetoric, stylistics), but also involve the latest disciplines (pragmalinguistics, suggestive and communicative linguistics), neurolinguistic programming, cognitive, neuro and psycholinguistics, etc.).

\section{Research Methods}

In the process of achieving the goal, the following methods are applied: descriptive to highlight the nature of the communicative influence; specifics of the review of influence in philosophy and linguistics; a method of analysis and synthesis for the identification of the components of communicative influence and the combination of their single complex; modeling method for constructing the degree of suggestiveness expression; the induction method served to conclude the general conclusions.

\section{Discussion}

P. A. Florensky skillfully described the "magical" power of the word in the sense of its influential potentials: "A magically powerful word does not need ... of course individuallypersonal tension of will or even a clear consciousness of its meaning. It itself concentrates the energy of the spirit ..., directed away from where it is directed by the very act of intention ... And speech, as it is not considered powerless, operates in the world, creating a similar" (Florensky, 2000, p. 249). O. T. Yudanova (2003) explains the contextual uses of P. A. Florensky 
for the word "magically" as "energized", and the words "magic" as actions aimed at using these energies by the will of man, emphasizing that in P. A. Florensky's terminology "Magic of the word" is a language suggestion (p. 23). Emphasizing the powerful power of the word, R. Barthes (1996) also emphasized that the proper "word is a form of power" (p. 93), since the subject of influence can control the object of influence. Analyzing the works of M. Heidegger, the scientist S. M. Kvit (2003) distinguishes such a basic position as the important role of language, which is the central component of influence in human life: "Man behaves as if he were the creator and master of language, while in fact, it is the language that owns it" (p. 59), that is, "not only does the creator create the language, but also lends itself to the power of language by the act of linguistics" (Kies, 2002, p. 100). Thus, the language has "magical" properties, that is, a powerful influential potential, it controls a person, dominates it, induces certain speech or behavioral actions that are aware and emphasized by known representatives of world philosophical thought.

V. Humboldt (1984) emphasized the close connection between spirit and soul with psychophysiological phenomena: "Language is the united spiritual energy of the people, miraculously imbued with certain sounds, in this embodiment and through the interconnection of their sounds, it is understood by all speakers and evokes approximately the same energy in them" (p. 349). In reflecting on O. O. Potebnya's views on the role of language in human life, R. Kies notes that the scientist also relied on V. Humboldt's opinion: "Potebnya considered language not only as a means of expression or expression of thought, but also as an active factor in the formation of thought, creation, construction of the spiritual world of man" (Kies, 2002, p. 100), which resonates with J. Lacan's (1953) belief that "language structures the person", modifying the processes of perception, understanding and thinking in each linguistic-national circle in their own way (see Kies, 2002, pp. 100-101) according to the psychological characteristics of the individual.

According to G. A. Goncharov, there are two philosophical views on the phenomenon of influence: idealistic and materialistic (Goncharov, n.d.), where the idealistic is that "the spirit is primary, and matter is secondary, derived from the spirit, subordinated to the principle of causality, time and space categories; the spirit is free, it does not know causal dependence, acts out of time and space" (Goncharov, n.d.). From the point of view of the materialistic view of influence, the spirit, the soul are derivatives of the brain, its function; psychic phenomena are inextricably linked to the brain physiological processes and with them are strictly determined, occurring in time and space (Goncharov, n.d.) that is, the mental and spiritual state characterize, determine certain mental processes of man, which attests to the extraordinary importance of the linguistic aspect of the phenomenon of influence, since Language can influence the spiritual world of a person, structure and construct it accordingly.

The powerful influential ability of language is based on the well-known hypothesis of the linguistic relativity of Sapir - Worf, which, in turn, is based on the ideas of W. Humboldt, where language imposes on man norms of cognition, thinking and social behavior: we can only know, understand and realize which is embedded in our language (Cherepanova, 2001, p. 35), and therefore, "the knowledge of the world depends on the language used by the subject of cognition" 
(Krongauz, 2001, p. 108). E. Sapir formulates the thesis about the influence of language on the life of society in this way: it is impossible to realize reality without the help of language, linguistic norms, which is why the so-called the real world. In turn, the perception of different phenomena is based on the fact that the relevant linguistic norms imply a certain form of expression (Krongauz, 2001, p. 107). B. Worf gave this conclusion the nature of the universal paradigm, according to which language is a mediator between individual thinking and the conventional representation of the individual, which specifies: a) the structure and orientation of our thinking (its paternization); b) the gestalt of our worldview; c) normative structures of behavior (Nastin, 2007, p. 12). According to D. P. Pashinina (2002), the Sapir-Worf hypothesis "sufficiently rigidly determines the suggestive role of language... Language does not simply impose norms that seem natural and ancient to us, it structures the world in a certain way, creating its own mesh through which we perceive the world and ourselves. Influence-suggestion comes from our own language, subordinating us to our own logic and invisibly diverting the speaker into our own element" (p. 377). This concept is refined in structural linguistics, where language as a determinant of a way of organizing collective and individual experience is understood not so much in the cognitive aspect (because knowledge of the world is possible through acts of pure perception and experience of individual moments of being), but in communicative (in internal or interpersonal) broadcast of the perceived) (Nastin, 2007, p. 12).

F. Bacon, M. Heidegger, A. Korzhibsky, J. Locke and others have emphasized the inaccuracy of perception and variability of reflection (rather than interpretation) of reality by different individuals. Analyzing the achievements of $\mathrm{H}$.
Weihinger and the founder of general semantics A. Korzhibsky, T. Y. Kovalevska (2008) explains the inaccuracy of reality and the perceived (interpreted) by us this reality "universal laws inherent in the transformational processes of mental objectifications, deterministic and structurally, - genetic and individual filters" (pp. 44 45), which seem to "cut off", "sort out" unnecessary information in case of inconsistency, convinced In contrast, if the information provided is of interest, it is skipped further for more detailed processing, which allows the recipient to be influenced without various barriers. Describing human communicative properties, A. Korzhybsky introduced the theory of "the identity of the objective world and its subjective model as a representative map of the environment" (Kovalevska, 2008, p. 44), based on at least three principles: the map is not a territory (words have many meanings); the map shows only part of the territory (any statement is polyphonic); maps condense the territory (the big picture is made up through the study, assimilation and generalization of many pictures, impressions and information on the same subject) (Kvit, 2008, p. 46), which essentially corresponds to the postulates of neurolinguistics programming (one of the sciences of influence) and form its philosophical basis (Kovalevska, 2008, p. 44). Considering these postulates significantly enhances the optimization of communication and details the concept of the philosophical nature of influence as such.

A. N. Baranov (2003) notes that "one of the first questions about the influence of language on the perception of reality and, accordingly, about its alternative interpretations, was raised by $\mathrm{F}$. Bacon in the "New Organ", explaining the process of human cognition and false conclusions "idols" or "Ghosts" " (p. 214). S. Kvit notes that 
M. Heidegger emphasized in this aspect that "the inaccuracy of a statement distorts reality, and therefore the very existence" (Kvit, 2003, p. 59), which raises the question of intentionality or unintentionality of distortion of the real world, the intentional misrepresentation of the information provided produces such an incorrect kind of influence as manipulation.

J. Locke also attributed the deliberate opacity of expression to the characteristic signs of influence; the use of words to nominate what they cannot indicate; the use of expressions with broad semantics (truth, idea, people, etc.); the excessive imagery of speech (Locke, 1960), which is also inherent in linguistic mechanisms of variant interpretation of reality, which dampens the influential activity of speech (Baranov, 2003, p. 214 ), directing the vector of perception in the direction desired for the interlocutor.

Explaining the influence of language in its working sense also attracted the attention of philosophers such as H. Feichinger, L. Wittgenstein and others. L. Wittgenstein (1994), highlighting the pragmatic aspect of language, noted that "even when confronted with a fundamentally new case, we are still captivated by models, images, and ways of using words worked out for other cases" (p. 94). Analyzing the imaginary future of people and the material present, H. Feichinger argued that people are more influenced by their expectations about the future than by real past experiences. The truth, according to $\mathrm{H}$. Feichinger, is "the most acceptable mistake, that is, the system of ideas that enables us to act and deal with any thing most quickly, clearly and safely, and with a minimum of irrational elements" (Feichinger, 2017). That is, the person is not in the present reality, but in an illusory world, and in many cases such perception is forced from the outside and at repeated repetition becomes stereotyped, which blocks the critical perception of information.

Thus, the philosophical basis of influence is the idea of the powerful influential potential of the word, its "magic" properties and the deep connection of the word with the spirit, soul, worldview and understanding of the external and internal world of man.

Given the priority nature of the language component in the general architectonics of the phenomenon of influence, further attention is focused on the corresponding refinement of representatives of linguistic science.

On the powerful force of the verbal component of suggestive influence was emphasized by the well-known scientist B. F. Porsnev, who in his fundamental works advanced the suggestive theory of the origin of language, confirming the hypothesis by the information of neurophysiologists that from all areas of the brain, the person is able to the second signaling system, evolutionarily older than the others, primary than others - the frontal lobe, including the prefrontal brain (Cherepanova, 2001, p. 30). B. F. Porshnev (1974) first noted that suggestion in primitive society was " ... a means of influencing people on the actions and behavior of others, that is, a special system of regulating behavior" (p. 415). Thus, the hypothesis about the role of suggestion at the beginning of history led the scientist to the extraordinary assumption of the essence of the second signaling system, or the language by which suggestion was carried out. The second signaling system is, first and foremost, "inflationary communication, that is, having a direct effect on the response. Direct influence (inflation) is the simplest socio-psychological phenomenon ... Impact is inseparable from speech" (Porshnev, 1972, p. 11 , which indicates the mandatory presence of an influential component to a greater or lesser 
extent in the communication process.

The great scientist O. O. Potebnya (1993) stated: "The power of human thought is not that the word evokes the former perception (it is possible without words) in the mind, but how it forces man to use the treasures of his past" (p. 97), that is, a person uses his or her previous experience as embodied in words. This is supported by J. O'Connor (2006), a researcher in the newest discipline in neurolinguistic programming: "Words are anchors of experience, they reinforce a certain state, reflect ideas and lead to understanding" (p. 220). From NLP's point of view, "language is a filter. It is a map of our thoughts and experiences, separated from the real world" (O'Connor \& Seymour, 1998, p. 20), and it is the suggestor who offers illusory reality commensurate with the human experience, enabling him to establish a report with further imposition of the necessary information. to perform certain speech and behavioral actions.

O. V. Kotlyachkov and S. A. Gorin (2007) also point out the powerful influence of the word: "Describing the experience for people is as real as the actual experience (qualitatively but not quantitatively)" (p. 19), because the word causes images, associations and the corresponding reaction of the organism - motor, sound, tactile, taste, contains energy influence, that is, triggers powerful energy processes (Petrenko \& $\mathrm{Ku}$ cherenko, 2000). These provisions are also supported by the English researcher J. Vitale (2008): "Certain words and phrases push the subconscious buttons of a person. It responds without realizing it" (p. 31), which generally reflects the need for accurate, careful selection of lexemes and linguistic complexes to create the most influential text.

Therefore, the word is a powerful weapon of conscious/unconscious processes, as it has the ability to reflect and shape the human mental experience. Penetrating to the level of deep structures with the help of certain words, the addressee can detect and influence the hidden psychic processes reflected in the addressee's speech patterns (Zheltukhina, 2003, p. 16). In addition, "human experience greatly exceeds the vocabulary, one word can cause different associations in different people. This often leads to the identification or confusion of two or more situations, that is, to generalization and double meaning" (Zheltukhina, 2003, p. 16), which in many cases forms the basis of suggestive-manipulative techniques of communicative influence. A. R. Luria, one of the founders of neurolinguistics, emphasized that with the emergence of language the world seems to be doubling (Petrenko \& Kucherenko, 2000), and in this case "We are doomed to perceive only the image of the world that we build in our language and through language" (Nastin, 2007, p. 33). In addition, "even if most of the information flows to a person through non-lingual channels, it is assimilated and influenced only through word processing" (Cherepanova, 2014), where in this case the linguistic component becomes more important than other components of communicative influence.

Language can generally be regarded as a suggestive phenomenon, that is, all components of a language are potentially suggestive (Murzin, 1995, p. 361; Cherepanova, 2001, p. 70), which supports many scholars (see the works of T. Y. Kovalevska, O. O. Selivanova and others). In addition, researchers believe that "any act of communication is suggestive - if the latter is understood not only and not the expansion of external information in the inner mental world of the subject, how much initiation in the subject of his own discursive-sensory associative network" (Nastin, 2007, p. 36). R. M. Blakar (1979) gener- 
ally argued that "language is an instrument of social power" (p. 133), because ... "the choice of utterances made by the addressee of the message influences the recipient's understanding. Even if the sender tries to "express himself objectively", it can be seen that the choice made by him expresses and predetermines the reception received by the recipient” (Blakar, 1987, p. 90), and “... any use of language implies such a structuring and influential effect. that is, neutral is impossible" (Blakar, 1987, p. 91). In this aspect, R. Lakoff (1990) states that "we all manipulate language and do it constantly" (p. 11), and note that this process takes place not only consciously but also unconsciously.

V. Z. Demyankov (1989) also notes in this aspect that "language with its vague semantics enables one to flexibly enter into another's consciousness: a new perspective, flexibly modifying itself (in this analogy with communicative mimicry) under the influence of the context of existing thoughts at the same time supersedes established thoughts in their system". In this way, the language itself allows for a variety of descriptions of reality, that is, it activates the ability of the language to change our understanding of certain objects, calling them different words this is called a variational interpretation of reality (or semantic manipulation). The specific feature of the language (see the works of A. N. Baranov, M. R. Dushkina, O. S. Issers, etc.) is specified and is used under communicative influence in order to conceal, camouflage the communicative intent. Accordingly, the interlocutor may impose on the recipient a certain (necessary!) conception of the environment, using a range of suggestive means that are actualized at different linguistic and textual and discursive levels (see the works of I. A. Avdeenko, R. M. Blakar, S. V. Boltayeva, N. V. Vertyankina, M. R. Zheltukhina, T.
Y. Kovalevska, O. V. Kotlyachkov, N. O. Ostroushko, I. Y. Cherepanova, N. V. Chumicheva, A. V. Shelestyuk, E. E. Schubert, and others).

Typically, all of the above levels interact, enhancing the impact (Kutuza, 2015, p. 118), and scientists, while analyzing impact actualizers, consider them simultaneously at several linguistic levels, noting the leading, but the views of scholars on the subject do not overlap. For example, I. Y. Cherepanova, based on the achievements of S. V. Voronin, O. P. Zhuravlev, J. Mystryk, R. G. Mshvidobadze, V. V. Nalimov, B. F. Porshnev, R. Yakobson, L. P. Yakubinsky and others, distinguishes 5 levels of suggestivelinguistic analysis: 1) phonological (phonosemantics); 2) prosodic (melody, accent, temporal and timbral characteristics, rhythm); 3) vocabulary (stylistic indexes by J. Mystrick); 4) vocabulary (definition of the percentage of words that represent different parts of the language); 5) morpho-syntactic (Cherepanova, 2001, pp. 7184). The author considers phonosemantic to be the leading level, in this aspect it is supported by such researchers as S. V. Boltayeva, O. V. Kotlyachkov, N. V. Chumicheva and others. The well-known scientist B. F. Porshnev recognizes morphological as the main level, but most researchers consider the lexico-semantic to be the center of linguistic suggestion (see the works of R. M. Blakar, S. A. Gorin, T. Y. Kovalevska and others). Moreover, according to the beliefs of the sponsor of suggestive linguistics I. Y. Cherepanova (2001), when constructing a hierarchy of levels of suggestive linguistics, one must take into account the heterogeneity of suggestion, that is, depending on the type of influence - hidden (latent) or open (different), respectively, here: phonological in latent, morphological (for example, the prescriptive way of the verb), etc. (p. 71). However, we support the view of T. Y. Ko- 
valevska that the semantic level is a suggestive concentrator and we propose to consider the actualizers of influence (suggestive/suggestogenic) at all linguistic levels in synthesis with the semantic: 1) grapheme, 2) phonetic, 3) prosodic, 4) word formation, 5) lexical, 6) morphological, 7) syntactic, 8) stylistic, where predominantly suggestions are actualized at several levels simultaneously, and semantic is cross-cutting. We also consider it advisable to consider sugestems/suggestogens by the degree of intensity of actualization of suggestive saturation (by analogy to the degrees of intensity of the connotated marking of ergonomics (Kutuza, 2015, p. 174): implementation at two language levels - weak actualization; that will allow us to more thoroughly explore the potential suggestiveness of various discourses.

Thus, the language system as a whole acts as a pivotal component of the influence, which determines the need for a thorough analysis of its active multilevel suggestogens.

\section{Conclusion}

Thus, in each of the natural, social and human sciences, a separate component of a multicomponent, complex phenomenon of influence is analyzed, which qualifies it as an interdisciplinary object of study. Philosophy also did not overlook the study of aspects of influence and suggestion as a variant of it. In the process of thinking about language, its influence on the spiritual world of man, his views and actions, etc., scholars focused their attention on such issues as the "magic" of words; close connection of spirit, soul with psycho-physiological phenomena, language and the influence of language on human perception; inaccuracy and variability of interpretation of reality; language as activity, motives for action, etc.
However, we note the priority character of the linguistic component in the general architectonics of the phenomenon of influence, where language is generally regarded as a suggestive phenomenon, given the ability to variably describe real reality through imagery, associativity, etc., based on the individual's prior experience. The most powerful areas of influence research are the latest trends in suggestive linguistics and NLP.

Thus, consideration of the achievements of various sciences (psychology, medicine, sociology, etc.), connected in one way or another with the phenomenon of influence, will allow to study as deeply and thoroughly as possible the said phenomenon, to understand global processes and specific conditions of its implementation, etc., since this The phenomenon has a complex nature, the components of which (psychological, physiological, linguistic, etc.) are deeply studied in the relevant fields.

\section{REFERENCES}

Baranov, A. N. (2003). Vvedenie v prikladnuyu lingvistiku (Introduction to Applied Linguistics, in Russian). Moscow: URSS Editorial.

Barthes, R. (1996). Mifologiya (Mythology, in Russian). Moscow: Publishing House Sabashnikovs.

Blakar, R. M. (1979). Language as a Means of Social Power. In Pragmalinguistics. The Hague (pp. 131-169). Paris: Mouton.

Blakar, R. M. (1987). Yazyk kak instrument sotsial'noy vlasti (teoretiko-empiricheskie issledovaniya yazyka i ego ispol'zovanie $v$ sotsial'nom kontekste) (Language as an Instrument of Social Power (The- 
oretical and Empirical Studies of Language and its Use in a Social Context), in Russian). In Language and modeling of social interaction (pp. 88-125). Moscow: Progress.

Cherepanova, I. Y. (2001). Dom koldun'i. Yazyk tvorcheskogo Bessoznatel'nogo (House of the Sorceress. The Language of the Creative Unconscious, in Russian). Moscow: KSP +.

Cherepanova, I. Y. (2014). Rossiyskaya suggestivnaya lingvistika - vernonapravlennoye vliyaniye yazyka na podsoznaniye lyudey (Russian suggestive linguistics the loyal influence of language on the subconscious of people, in Russian). Word of Linguistics and Communication, 2(35), 1-4. Retrieved March 19, 2020 from: http://tverlingua.ru.

Demyankov, V. Z. (1989). Effektivnost' argumentatsii kak rechevogo vozdeystviya (The Effectiveness of Argumentation as a Speech Effect, in Russian). The Problems of Effectiveness of Speech Communication, 13-40. Retrieved March 20, 2020 from: http://www.infolex.ru /P048.html.

Feichinger, G. (2017). Filosofiya kak esli by (Philosophy as if, in Russian). Retrieved March 19, 2020 from: https://psychosearch.ru/biblio/filosof/hans-vaihinger/423-kniga-gans-fajkhinger-filosofiya-kak-esli-by-chast-1-predislovie-isoderzhanie.

Florensky, P. A. (2000). Sochineniya v 4 tomakh (Works in 4 volumes, in Russian). (Vol. 3). Moscow: Thought.

Goncharov, G. A. (n.d.). Suggestiya: teoriya I praktika (Suggestion: Theory and Practice, in Russian) Retrieved March 20,
2020 from: http://www.universal internetlibrary.ru/book/goncharov/ogl.shtml. Humboldt, V. (1984). Izbrannye trudy po yazykoznaniyu (Selected Works on Linguistics, in Russian). Moscow: Progress.

Kies, R. (2002). Mova, dumka i kul'turna real'nist' (vid Oleksandra Potebni do teoriyi movnoho relyatyvizmu) (Language, Thought, and Cultural Reality (from Alexander Potebna to the Theory of Linguistic Relativism), in Ukrainian). Lviv: Chronicle.

Kotlyachkov, A., \& Gorin, S. (2007). Oruzhiye slovo. Oborona i napadeniye s pomoshch'yu... (Weapons - the Word. Defense and Attack with the Help of..., in Russian). Moscow: KSP +.

Kovalevska, T. Y. (2008). Komunikatyvni aspekty neyrolinhvistychnoho prohramuvannya (Communicative Aspects of Neurolinguistic Programming, in Ukrainian). Odessa: Astroprint.

Krongauz, M. A. (2001). Semantika (Semantics, in Russian). Moscow: Russian State University for the Humanities.

Kutuza, N. V. (2015). Reklamnyy ta PR-dyskurs: aspekty vplyvu (Advertising and PR Discourse: Aspects of Impact, in Ukrainian). Kiev: Dmitry Burago Publishing House.

Kvit, S. (2003). Osnovy hermenevtyky (Fundamentals of Hermeneutics, in Ukrainian). Kyiv: Kyiv-Mohyla Academy Publishing House.

Kvit, S. (2008). Masovi komunikatsiyi (Mass Communications, in Ukrainian). Kyiv: Kyiv-Mohyla Academy Publishing House.

Lacan, J. (1953). Funktsiya i pole rechi i yazyka $v$ psikhoanalize (Function and Field of 
Speech and Language in Psychoanalysis, in Russian). Report at the Rome Congress, read at the Institute of Psychology, University of Rome, September 26 and 27. Retrieved March 20, 2020 from: http://teneta.rinet.ru/rus/le/lakan.htm.

Lakoff, R. (1990). Talking Power. The Politics of Language. New York: Free press.

Locke, J. (1960). Opyt o chelovecheskom razumenii (The Experience of Human Understanding, in Russian). In J. Locke, Selected Philosophical Works, I (pp. 153-162). Moscow: Publishing House of Social and Economic Literature.

Manakin, V. M. (2011). Suhestyvna funktsiya movy yak prahmalinhvistychne yavyshche (Suggestive Function of Language as a Pragmalinguistic Phenomenon, in Ukrainian). Studia Linguistica, II, 196203.

Murzin, L. N. (1995). O dinamicheskoy lingvistike XX veka (On Dynamic Linguistics of the XX Century, in Russian). Linguistics at the End of the Twentieth Century: Results and Prospects, II, 361-362. Moscow: Philology.

Nastin, I. V. (2007). Psikholingvistika (Psycholinguistics, in Russian). Moscow: Moscow Psychological and Social Institute.

O'Connor, J. (2006). NLP: Prakticheskoe rukovodstvo dlya dostizheniya zhelayemykh rezul'tatov (NLP: A Practical Guide to Achieving Desired Results, in Russian). Moscow: FAIR.

O’Connor, J., \& Seymour, J. (1998). Vvedeniye v NLP (Introduction to NLP, in Russian). Chelyabinsk: Version.

Pashinina, D. P. (2002). Vlekomye yazykom (Drawn by Language, in Russian). Phi- losophy of Science, VIII, 377-405.

Petrenko, V. F., \& Kucherenko, V. V. (2000). Iskusstvo suggestivnogo vozdeistviya (Art of Suggestive Influence, in Russian). The Journal of Practicing Psychologist, 6. Retrieved March 19, 2020 from: https://shust.me/iskusstvo-suggestivnogo-vozdejstviyal.

Porshnev, B. F. (1972). Kontrsuggestiya i istoriya (Elementarnoye sotsial'no-psikhologicheskoe yavlenie i ego trasformatsii v razvitii chelovechestva) (Counter-Suggestion and History (Elementary SocioPsychological Phenomenon and its Transformations in the Development of Mankind), in Russian). History and Psychology, 7-35.

Porshnev, B. F. (1974). O nachale chelovecheskoi istorii. Problemy paleopsikhologii (Beginning of Human History. Problems of Paleo-Psychology, in Russian). Moscow: Thought.

Potebnya, A. A. (1993). Mysl' $i$ yazyk (Thought and Language, in Russian). Kiev: SINTO.

Vitale, J. (2008). Gipnoticheskiye reklamnye teksty: kak iskushat' i ubezhdat' kliyentov odnimi slovami (Hypnotic Advertising Texts: How to Tempt and Convince Customers in One Word, in Russian). Moscow: Eksmo.

Wittgenstein, L. (1994). Filosofskie issledovaniya (Philosophical Studies, in Russian). In L. Wittgenstein, Philosophical Work (Part 1, pp. 75-319). Moscow: Gnosis.

Yudanova, E. T. (2003). Suggestivnaya funktsiya yazykovykh sredstv angloyazychnogo politicheskogo diskursa (Suggestive Function of Linguistic Means of Engish-language Political Discourse, in 
Russian). St. Petersburg.

Zheltukhina, M. R. (2003). Mass-medial'naya kommunikatsiya: yazykovoye soznaniye - vozdeystviye - suggestivnost' (Mass-
Media Communication: Linguistic Consciousness - Impact - Suggestiveness, in Russian). Language. Consciousness. Communication, 24, 13-28. 